\title{
Strawberry (Fragaria $\times$ ananassa Duch.) Growth and Productivity as Affected by Temperature
}

\author{
Sorkel Kadir ${ }^{1}$ and Gaganpreet Sidhu \\ Department of Horticulture, Forestry, and Recreation, Kansas State \\ University, Manhattan, KS 66506
}

Kassim Al-Khatib ${ }^{2}$

Agronomy Department, Kansas State University, Manhattan, KS 66506

Additional index words. 'Chandler', 'Sweet Charlie', photosynthesis, relative chlorophyll content, chlorophyll fluorescence

\begin{abstract}
Thermotolerance of photosynthesis and productivity in 'Chandler' and 'Sweet Charlie' strawberry plants (Fragaria Xananassa Duch.) exposed to three temperature regimes was studied. Net $\mathrm{CO}_{2}$ assimilation rate (A), variable chlorophyll fluorescence (Fv), efficiency of photosystem II (Fv/Fm), relative chlorophyll content, plant growth, and fruit yield and quality were measured. High temperature $\left(40^{\circ} \mathrm{C}\right.$ day $/ 35^{\circ} \mathrm{C}$ night $)$ was more detrimental to photosynthesis and productivity than the moderate or low temperature $\left(30 / 25\right.$ or $\left.20 / 15{ }^{\circ} \mathrm{C}\right)$. Net $\mathrm{CO}_{2}$ assimilation rate in both cultivars was markedly reduced by $40 / 35{ }^{\circ} \mathrm{C}$, although there was slight decline in 'Sweet Charlie' at $30 / 25{ }^{\circ} \mathrm{C}$. 'Chandler' maintained significantly higher A rates than 'Sweet Charlie' for at least three weeks of heat stress, indicating that 'Chandler' might tolerate longer exposure to high temperature. In parallel to the decrease in $\mathrm{A}$ rate, intercellular $\mathrm{CO}_{2}$ concentration $\left(C_{i}\right)$ and instantaneous water use efficiency (WUE) were significantly decreased at high temperature. 'Chandler' leaves were cooler and transpired more than 'Sweet Charlie' leaves, suggesting that each cultivar adopted different heat resistance mechanisms at $40 / 35^{\circ} \mathrm{C}$. There were changes in $\mathrm{Fv}$ and $\mathrm{Fv} / \mathrm{Fm}$ with increasing temperature, indicating irreversible damage to photosystem II at $40 / 35{ }^{\circ} \mathrm{C}$ might have occurred. The trend of reduction in stomatal conductance $\left(g_{S}\right)$ in both cultivars at high temperature did not coincide with the reduction in A rates. Decline in A rates at high temperature was more related to changes in $\mathrm{Fv} / \mathrm{Fm}$ than to $g_{S}$ activity. The optimal temperature for vegetative growth was $30 / 25{ }^{\circ} \mathrm{C}$. Reduction in A rate at high temperature resulted in reduction in total leaf area (LA), shoot, root, and leaf biomasses. Strawberry roots were more responsive than shoot growth to temperatures above $20 / 15{ }^{\circ} \mathrm{C}$. Fruit yield for 'Chandler' was higher at $20 / 15{ }^{\circ} \mathrm{C}$ than at $30 / 25^{\circ} \mathrm{C}$, suggesting that 'Chandler' might have a higher source-to-sink relationship at $20 / 15^{\circ} \mathrm{C}$ than at $30 / 25^{\circ} \mathrm{C}$. Fruit skin color was temperature dependent only for 'Chandler'. A quadratic relationship between flower development and duration of exposure to $30 / 25^{\circ} \mathrm{C}$ for both cultivars was observed; more than two weeks of $30 / 25{ }^{\circ} \mathrm{C}$ can be detrimental to flower development. Regardless of the cultivar and duration of exposure, $40 / 35^{\circ} \mathrm{C}$ was the temperature regime most detrimental to fruit set.
\end{abstract}

Strawberry cultivars grown in specific areas are adapted to the day length and temperatures of that region. Nevertheless, heat stress is one of the challenges that face strawberry production. Reduction in plant growth by high temperatures is well established in horticultural crops such as tomato (Solanum lycopersicum L.) (Adams et al., 2001), grape (Vitis spp.) (Chaumont et al., 1997), and strawberry (Renquist et al., 1983).

Received for publication 24 May 2006. Accepted for publication 9 July 2006. With our appreciation, funding for this study was provided by the Initiative for Future Agricultural Food System, U.S. Department of Agriculture (IFAFS/USDA), and Kansas Agricultural Experiment Station. This is contribution no. 06-265-J from the Kansas State Agricultural Experiment Station.

${ }^{1}$ To whom reprint requests should be addressed; e-mailskadir@ksu.edu.

${ }^{2}$ Professor, Agronomy Department.
Damage to crops by high temperatures has been reported in many regions around the world and Kansas is no exception; temperatures above $35^{\circ} \mathrm{C}$ are common during the growing season.

High temperature adversely affects vegetative growth and fruit quality of tomato (Adams et al., 2001; Mulholland et al., 2003) and reproductive systems of peanut (Arachis hypogaea L.) (Vara-Prasad et al., 1999). Heat stress affects photosynthesis, which is highly sensitive to thermal inhibition (Henning and Brown, 1986) whether stress occurs early or late in the growing season. High temperature inhibits thylakoid activities, especially near the photosystem II (PSII) reaction center (Berry and Björkman, 1980).

There have been reports on responses of strawberry cells and whole plants to various temperatures. Strawberry cells subjected to $30{ }^{\circ} \mathrm{C}$ grew slowly and did not proliferate normally in suspension cultures (Zang et al.,
1997). Strawberry vegetative growth (Hellman and Travis, 1988), root growth (Fukuda and Matsumoto, 1988), fruit set (Nishiyama et al., 2003), pollen viability (Ledesma and Sugiyama, 2005), fruit weight (Mori, 1998), fruit quality (Polito et al., 2002), and leaf protein expression (Gulen and Eris, 2004; Ledesma et al., 2004) were negatively affected by high temperatures. However, strawberry plants resistant to high temperature have the ability to maintain high rates of photosynthesis, stabilize proteins, and synthesize new proteins (Gulen and Eris, 2004).

It has been established that the critical temperature range for strawberry growth inhibition is between 35 and $40^{\circ} \mathrm{C}$ and that development of runners is inhibited by $3 \mathrm{~d}$ of exposure to $40{ }^{\circ} \mathrm{C}$ (Hellman and Travis, 1988). Nevertheless, the mechanism involved in heat stress is not well defined, and information related to strawberry varietal response to heat stress manifested in direct effect on photosynthetic rate and indirect effect on the photosynthesis process is limited. Annual temperature fluctuation occurs frequently in Kansas from late spring through midsummer, a period characterized by high temperatures and long exposure that severely impact growth and production of strawberries.

In this respect, our objective was to investigate the effects of low, moderate, and high temperatures on physiological characteristics and productivity of 'Chandler' and 'Sweet Charlie' strawberry plants. Specific objectives were to identify the optimal temperatures for photosynthesis and chlorophyll fluorescence, determine the influence of high temperature on photosynthesis and efficiency of PSII, and to assess growth response and productivity of strawberry plants under three temperature treatments.

\section{Materials and Methods}

Plant materials and treatments. Two new June-bearing strawberry cultivars were selected to replace the old cultivars in Kansas. 'Chandler' and 'Sweet Charlie' are chosen for their early production, high yield, and quality fruits. Plug plants of 'Chandler' and 'Sweet Charlie' (Davon Crest Farms LLC, Hurlock, Md.) strawberry (Fragaria $\times$ ananassa) were planted 6 Aug. 2003 in polyethylene pots $(16.25 \times 16.25 \times 12.5 \mathrm{~cm})$ containing a mixture of 1 soil: 1 peatmoss: 1 perlite (by volume). Each pot had six drainage holes to facilitate water drainage. Plants were grown for 4 weeks under greenhouse conditions of $22 / 17 \pm 3{ }^{\circ} \mathrm{C}$ day/night $(\mathrm{D} / \mathrm{N})$ temperatures, $50 \pm 10 \%$ relative humidity $(\mathrm{RH})$, and $16 / 8$-h light/dark (L/D) photoperiods with 500 $\mu \mathrm{mol} \cdot \mathrm{m}^{-2} \cdot \mathrm{s}^{-1}$ PPF density (PPFD) (400-700 $\mathrm{nm}$, measured with LI-188B Integrating Quantum/Radiometer/Photometer and LI190sB sensor; LI-COR, Inc., Lincoln, Nebr.) on a horizontal plane above the plant canopy. Supplemental light was provided by Hydrofarm grow lights with 400-W, high-pressure sodium, S-51-type lamps (Hydrofarm Products, Petaluma, Calif.). Plants were irrigated 
as needed with deionized distilled water to full pot capacity (Olson et al., 2000). Full pot capacity was determined by saturating the dry soil with water and then measuring the increase in weight after water drained by gravity from the pot. Moisture was maintained by weighing the pots and replenishing water to full pot capacity. Plants were fertilized weekly with a commercial fertilizer containing $300 \mu \mathrm{g} \cdot \mathrm{L}^{-1}$ nitrogen $(\mathrm{N}), 250$ $\mu \mathrm{g} \cdot \mathrm{L}^{-1}$ phosphorus $(\mathrm{P})$, and $220 \mu \mathrm{g} \cdot \mathrm{L}^{-1}$ potassium (K) (Miracle-Gro; Scotts MiracleGro Products, Port Washington, N.Y.).

Four weeks later, and before temperature treatments, the most recently fully expanded leaflet was measured to determine gas exchange, relative chlorophyll content, and chlorophyll fluorescence. Nine plants of each cultivar were randomly distributed into one of the three growth chambers (Conviron CMP 3244, Asheville, N.C.) set at 20/15 \pm $1{ }^{\circ} \mathrm{C}, 30 / 25 \pm 1{ }^{\circ} \mathrm{C}$, or $40 / 35 \pm 1{ }^{\circ} \mathrm{C}$ D/N temperatures, 16/8-h L/D photoperiods with $550 \mu \mathrm{mol} \cdot \mathrm{m}^{-2} \cdot \mathrm{s}^{-1} P P F D$, and $70 \% \mathrm{RH}$. Growth chamber lights were turned off between 10:00 PM and 6:00 AM. Plants were watered as needed to full pot capacity with deionized distilled water. Pest control was carried out according to strawberry pest control recommendations (Kadir et al., 2006).

Gas exchange, chlorophyll fluorescence, and relative chlorophyll content of the most recently fully expanded leaflet were measured at weekly intervals for 4 weeks between 9:00 AM and 11:00 AM. Open flower number was recorded and percentage of dead flower was calculated at weekly intervals. Total fruit yield and fruit quality were recorded as the strawberry plants grow; vegetative and root growth was determined after 4 weeks of exposure.

Leaf gas exchange measurement. Gas exchange was measured with an LI-6400 open system portable photosynthesis meter (LI-COR Inc.). Net $\mathrm{CO}_{2}$ assimilation rate (A), stomatal conductance $\left(\mathrm{g}_{\mathrm{s}}\right)$, transpiration rate $(\mathrm{E})$, intercellular $\mathrm{CO}_{2}$ concentration $\left(\mathrm{C}_{\mathrm{i}}\right)$, and leaf temperature were determined. Instantaneous water use efficiency (WUE) was calculated as the ratio between the photosynthetic and transpiration rates $(\mathrm{A} / \mathrm{E})$. A leaf sample was placed in the leaf chamber $(6.0$ $\mathrm{cm}^{2}$ ) and exposed to $550 \mu \mathrm{mol} \cdot \mathrm{m}^{-2} \cdot \mathrm{s}^{-1} P P F D$ and a $\mathrm{CO}_{2}$ concentration of $400 \mu \mathrm{L} \cdot \mathrm{L}^{-1}$. Data were recorded after 30 to $45 \mathrm{~s}$, when $\mathrm{CO}_{2}$ and $g_{\mathrm{S}}$ stabilized.

Leaf chlorophyll fluorescence measurement. Leaf chlorophyll fluorescence was determined by using a pulse-modulated fluorometer (Fluorescence Monitoring System [FMS-1]; Hansatech Instruments Ltd., Norfolk, U.K.). The FMS-1 requires no dark adaptation of the leaf because it uses modulated fluorometry to separate actinic light from the fluorescence signal. During measurements, a tissue sample is exposed to a pulsed amber LED light source causing excitation of a pulsed fluorescence signal in the absence of actinic light. The machine was operated in the Fv/Fm mode, and the fluorescence was measured with a photodiode in the 710- to 760-nm range. The fluorometer probe was placed $5 \mathrm{~mm}$ away from the leaf, and measurements were made at a steady state of $2000 \mu \mathrm{mol} \cdot \mathrm{m}^{-2} \cdot \mathrm{s}^{-1}$ and a saturating state of $5000 \mu \mathrm{mol} \cdot \mathrm{m}^{-2} \cdot \mathrm{s}^{-1}$ for $0.8 \mathrm{~s}$. Fluorescence parameters of initial fluorescence (Fo), maximal fluorescence (Fm), variable fluorescence $(\mathrm{Fv}=\mathrm{Fm}-\mathrm{Fo})$, and quantum yield efficiency of PSII (Fv/Fm) were recorded from the fluorescence LCD display. Three readings from locations between the veins were averaged to represent one observation.

Relative chlorophyll content measurement. An indirect index of chlorophyll content was measured with a leaf chlorophyll meter (SPAD-501; Minolta Corp., Osaka, Japan) at weekly intervals. Three SPAD measurements $\left(38 \mathrm{~mm}^{2}\right.$ total leaf area) from locations between the veins were averaged to represent one observation.
Plant growth and productivity. Individual plants were harvested after 4 weeks of temperature treatments and leaf, crown, and runner numbers were recorded. Total leaf area (LA) per plant was measured with the LI-3100 leaf area meter (LI-COR Inc.). Roots were extracted from the soil, washed with deionized distilled water, and placed on paper towels in the greenhouse for one day. Leaves, shoots (crowns and petioles), and roots were dried at $70{ }^{\circ} \mathrm{C} \pm 2$ for $72 \mathrm{~h}$ and were weighed.

Weekly observation of flower development was conducted in each growth chamber. Open flower number was recorded and percentage of dead flower was calculated based on total flower number per week in each temperature. Percentage of dead flower was determined by dividing total number of flower by number of dead flower and multiplying by 100 .
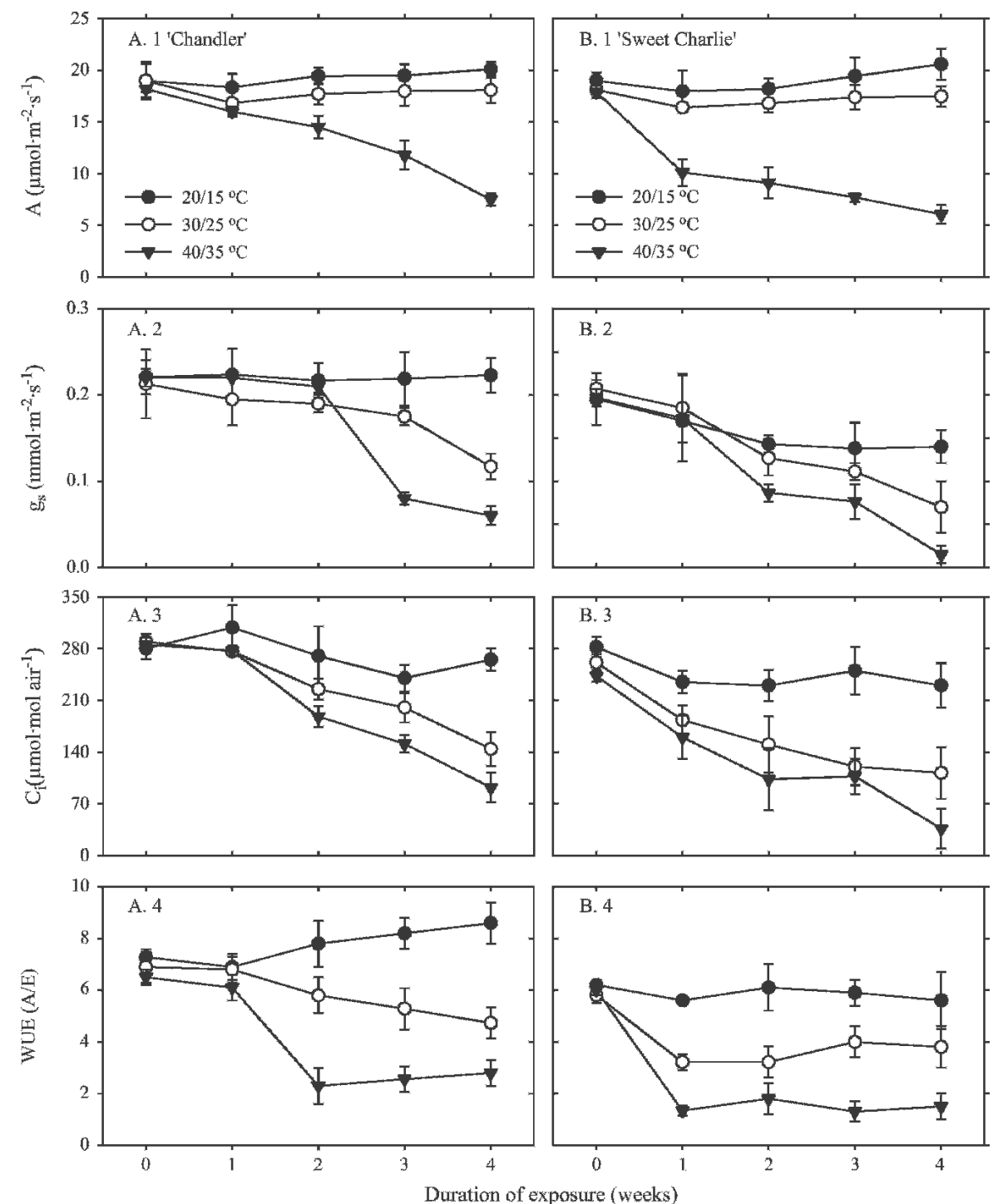

Fig. 1. Effect of three temperature regimes $\left(20 / 15,30 / 25\right.$, or $40 / 35{ }^{\circ} \mathrm{C}$ day/night $[\mathrm{D} / \mathrm{N}]$ and $16 / 8$-h photoperiod for 4 weeks) on net $\mathrm{CO}_{2}$ assimilation rate (A) (A.1 and B.1), $g_{\mathrm{S}}\left(\mathrm{g}_{\mathrm{s}}\right.$ ) (A.2 and B.2), intercellular $\mathrm{CO}_{2}\left(\mathrm{C}_{\mathrm{i}}\right)$ (A.3 and B.3), and instantaneous water use efficiency (WUE) (A.4 and B.4) of newly fully developed leaflet on 4-week-old 'Chandler' (A 1-4) and 'Sweet Charlie' (B 1-4) plants. Measurements were obtained at $\mathrm{CO}_{2}$ concentration of $400 \mu \mathrm{L} \cdot \mathrm{L}^{-1}$ at weekly intervals. Vertical bars through data points are standard errors; values smaller than symbols are not shown. Data represent means of nine plants grown in the same temperature regime. 
Fruits were harvested at full maturity (more than 90\% skin color). Fruit yield per plant and average fresh fruit weight were recorded. Soluble solids concentration (SSC) was measured from extracted juice with a handheld sugar refractometer (Atago No. 41385; Leslie Ratay, New Gardens, N.Y.) and a sucrose scale calibrated at $20{ }^{\circ} \mathrm{C}$. Three external fruit color measurements were taken with a Chromameter (CR-310; Minolta, Japan) according to the Hunter ' $a$ ', ' $L$ ', ' $b$ ' system and the results were averaged. The machine was calibrated with a white standard $(\mathrm{L}=97.83, \mathrm{a}=-0.38, \mathrm{~b}=1.94)$. The " $a$ " value represents greenish to redness, lightness coefficient " $L$ " represents brightness and darkness, and " $b$ " value represents blueish to yellowish. Hue value $\left({ }^{\circ} h\right)$ measures fruit color intensity and was calculated from a combination of Hunter " $a$ " and " $b$ " values (Hunter and Harold, 1987); the lowest ${ }^{\circ} \mathrm{h}$ represents the greatest degree of red skin color.

The experiment was a randomized complete block design with a factorial arrangement of cultivar $\times$ temperature $\times$ time. Temperature treatments were replicated two times; for the second replication, strawberry plants were planted in the greenhouse on 10 Jan. 2004; there was no interaction between treatments and replications; thus, data are averaged across replications. Temperature treatment response was determined by analysis of variance according to General Linear Models Procedure (SAS Institute, Cary, N.C.). Least significant differences (LSD) among means were tested at $P=0.05$. Standard errors of the means were calculated. Person correlation coefficients $(r)$ between selected parameters were established. Appropriate data were subjected to regression analysis to establish the coefficient of determination $\left(r^{2}\right)$ for the best model.

\section{Results and Discussion}

Gas exchange. Temperature and duration of exposure significantly interacted with cultivar to influence gas exchange parameters (Fig. 1). High temperature $\left(40 / 35{ }^{\circ} \mathrm{C}\right)$ was more detrimental to photosynthesis than moderate or low temperature $(20 / 15$ or $30 /$ $25{ }^{\circ} \mathrm{C}$ ). Net $\mathrm{CO}_{2}$ assimilation rates (A) of 'Chandler' (Fig. 1, A.1) and 'Sweet Charlie' (Fig. 1, B.1) in $20 / 15{ }^{\circ} \mathrm{C}$ were the same as those of plants in $30 / 25^{\circ} \mathrm{C}$, although a $15 \%$ decline was observed in 'Sweet Charlie' after 4 weeks of exposure to $30 / 25^{\circ} \mathrm{C}$. Regardless of the cultivar, plants grown in $40 / 35^{\circ} \mathrm{C}$ showed early decline in A rates. One and 2 weeks of exposure reduced A rates by $44 \%$ and $20 \%$ in 'Sweet Charlie' and 'Chandler', respectively, compared with the control. Photosynthetic rate in $40 / 35{ }^{\circ} \mathrm{C}$ at the end of the experiment was practically the same for both cultivars, but 'Chandler' maintained significantly higher A rates for at least 3 weeks of high temperature than 'Sweet Charlie'. These results indicate that photosynthetic rate in 'Chandler' remained higher at warm temperatures than that in 'Sweet Charlie'; the former might survive longer exposure to high temperature.

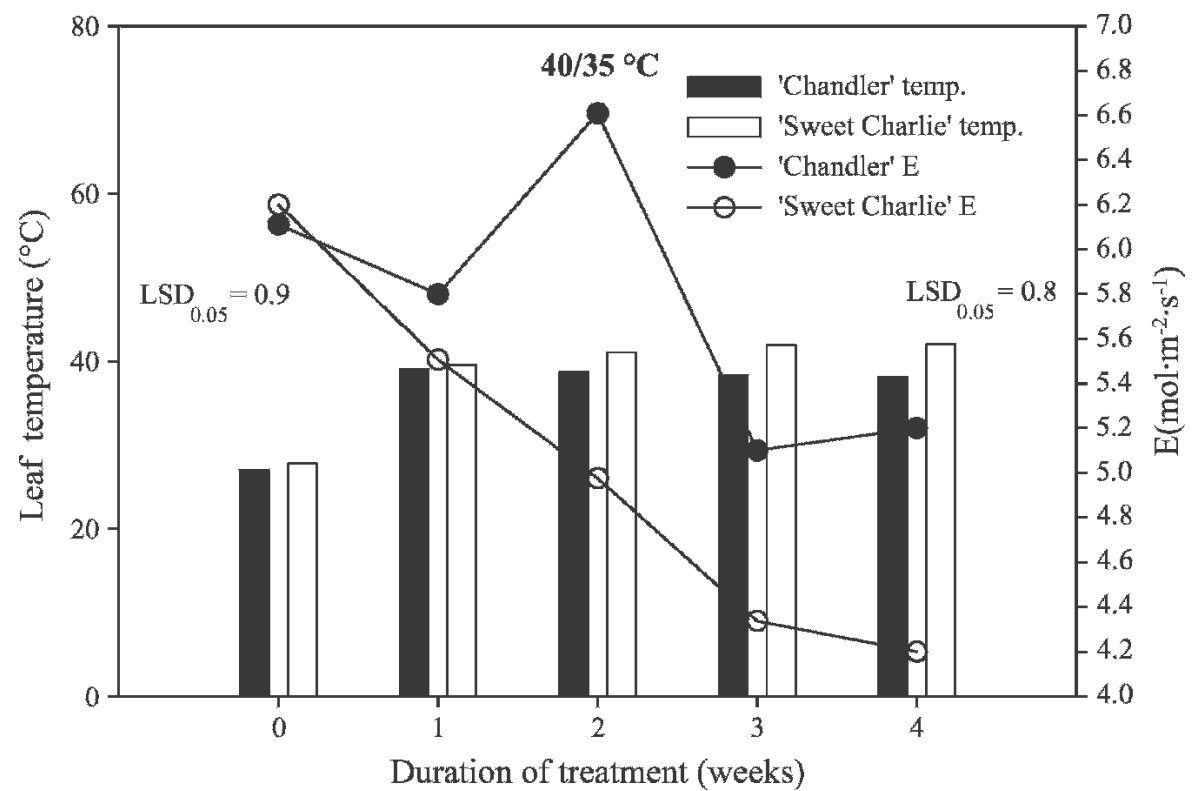

Fig. 2. Effect of high temperature $\left(40 / 35^{\circ} \mathrm{C}\right.$ day/night $[\mathrm{D} / \mathrm{N}]$ and $16 / 8$-h photoperiod for 4 weeks) on leaf temperature (bars) and transpiration rate (E) (circles) of newly fully developed leaflet on 4-week-old 'Chandler' (solid circles and bars) and 'Sweet Charlie' (open circles and bars) plants. Measurements were obtained at $\mathrm{CO}_{2}$ concentration of $400 \mu \mathrm{L} \cdot \mathrm{L}^{-1}$ at weekly intervals. Data represent means of nine plants grown in the same temperature regime.

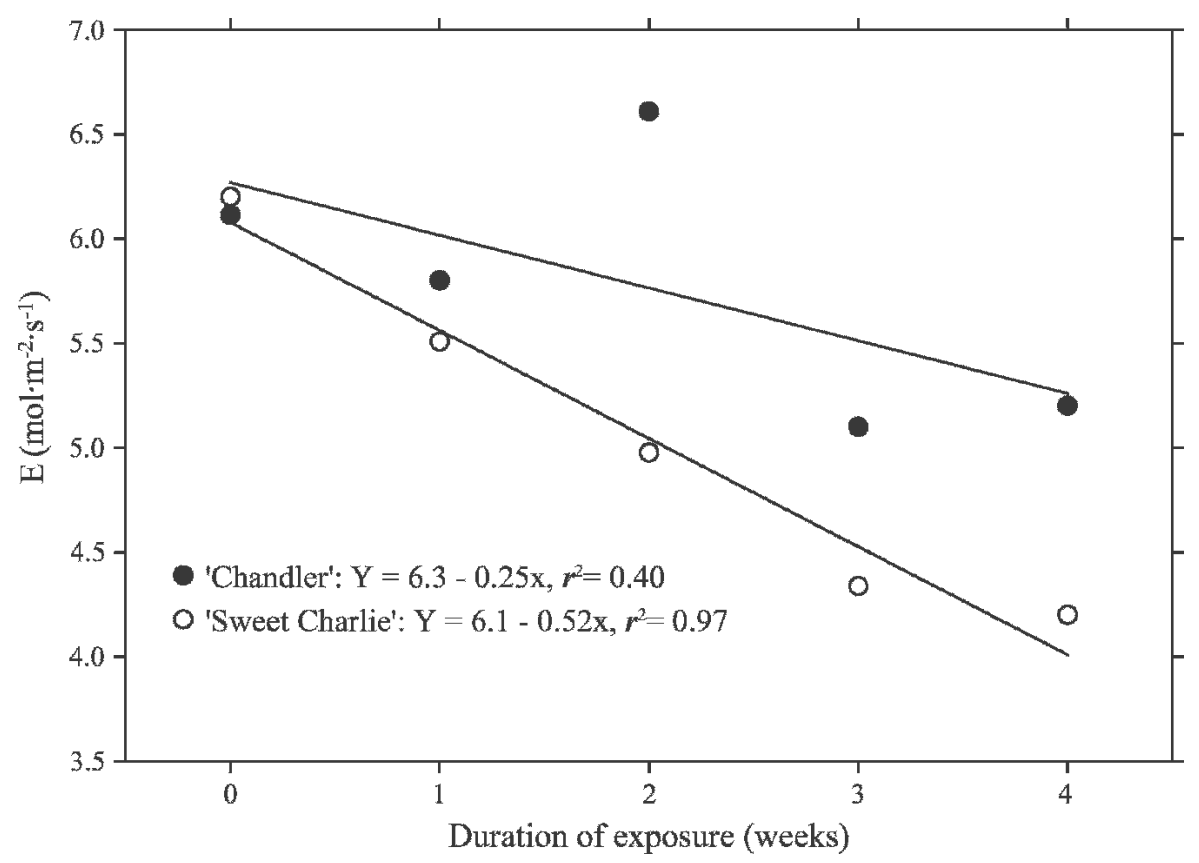

Fig. 3. Relationship between duration of exposure to high temperature $\left(40 / 35{ }^{\circ} \mathrm{C}\right.$ day/night $\left.[\mathrm{D} / \mathrm{N}]\right)$ and 16/8-h photoperiod for 4 weeks) and transpiration rate (E) of newly fully developed leaflet on 4-weekold 'Chandler' $(\bullet)$ and 'Sweet Charlie' $(\mathrm{X})$ plants. Measurements were obtained at $\mathrm{CO}_{2}$ concentration of $400 \mu \mathrm{L} \cdot \mathrm{L}^{-1}$ at weekly intervals. Lines represent linear regression analysis of the means. Data represent means of nine plants.

Initially, $g_{\mathrm{S}}\left(\mathrm{g}_{\mathrm{s}}\right)$ of both cultivars was the same, but reduction occurred in the $40 / 35^{\circ} \mathrm{C}$ treatment after 2 and 3 weeks of exposure in 'Sweet Charlie' (Fig. 1, B.2) and 'Chandler' (Fig. 1, A.2), respectively. Four weeks of exposure to high temperature reduced $\mathrm{g}_{\mathrm{s}}$ in 'Sweet Charlie' by $92 \%$ compared with $72 \%$ in 'Chandler'. Nevertheless, the $\mathrm{g}_{\mathrm{s}}$ of 'Chandler' was significantly higher than that of 'Sweet Charlie' at the end of the experiment, which might indicate that $g_{s}$ of 'Chandler' is relatively less responsive to high temperature than that of 'Sweet Charlie'. In both cultivars, a decline in $g_{s}$ at high temperature did not correspond to a decline in A rates. Different reduction trends of $\mathrm{A}$ rate and $\mathrm{g}_{\mathrm{s}}$ at high 

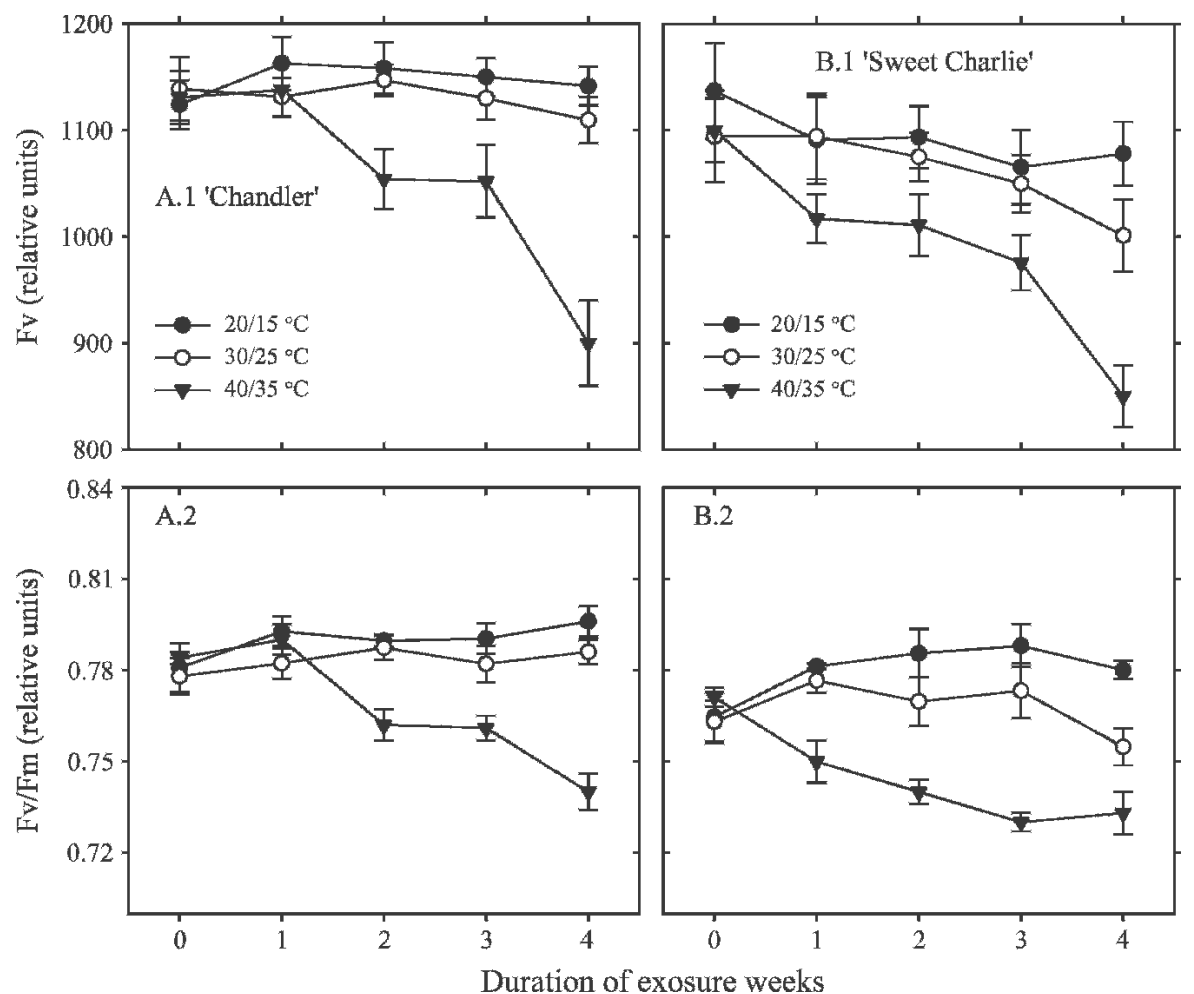

Fig. 4. Effect of three temperature regimes $\left[20 / 15,30 / 25\right.$, or $40 / 35{ }^{\circ} \mathrm{C}$ day/night $(\mathrm{D} / \mathrm{N})$ and $16 / 8-\mathrm{h}$ photoperiod for 4 weeks] on variable fluorescence $(\mathrm{Fv})$ and quantum yield efficiency of photosystem II (Fv/Fm) ratio of newly fully developed leaflet on 4-week-old 'Chandler' (A 1-2) and 'Sweet Charlie' (B 1-2) plants. Chlorophyll fluorescence was measured as described in the "Materials and Methods" at weekly intervals. Vertical bars through data points are standard errors; values smaller than symbols are not shown. Data represent means of nine plants grown in the same temperature regime.

temperature suggest that high temperature directly acts on limitation factors related to photosynthesis processes other than $\mathrm{g}_{\mathrm{s}}$ activities. This agrees with earlier report that $g_{s}$ usually is not involved in temperature effects on photosynthesis (Paulsen, 1994). High temperature affects photosynthetic processes through nonstomatal activities such as enzymatic activity during photosynthesis (Medrano et al., 2003).

Low temperature $\left(20 / 15{ }^{\circ} \mathrm{C}\right)$ had no influence on intercellular $\mathrm{CO}_{2}\left(\mathrm{C}_{\mathrm{i}}\right)$ concentrations in either cultivar. However, in $30 / 25$ and $40 / 35^{\circ} \mathrm{C}, \mathrm{C}_{\mathrm{i}}$ was reduced 1 week earlier in 'Sweet Charlie' (Fig. 1, B.3) than in 'Chandler' (Fig. 1, A.3). In contrast to 'Sweet Charlie', 'Chandler' maintained significantly higher $\mathrm{C}_{\mathrm{i}}$ concentrations for at least 3 weeks at $30 / 25{ }^{\circ} \mathrm{C}$. A linear decline for 'Sweet Charlie' and Chandler' in $40 / 35{ }^{\circ} \mathrm{C}$ was recorded after 1 and 2 weeks of exposure, respectively. After 4 weeks of high temperature, reduction was more severe in 'Sweet Charlie' (87\%) than 'Chandler' (68\%) compared with the control plants. Results indicate that timing of $\mathrm{C}_{\mathrm{i}}$ reduction in both cultivars coincided with a decrease in A rates but not $g_{s}$. This suggests that decline in $C_{i}$, which results in a decline in A rate, might also be related to factors other than $g_{\mathrm{S}}$ such as a decrease in mesophyll conductance (CandolfiVasconcelos and Koblet, 1991).

Instantaneous WUE measures the efficiency of carbon fixation per unit water loss.
For both cultivars, the rate of carbon gain was almost always higher than water loss (higher WUE) in $20 / 15$ and $30 / 25{ }^{\circ} \mathrm{C}$ than in $40 / 35$ ${ }^{\circ} \mathrm{C}$. The declining trend of WUE at high temperature was similar to the trend of $\mathrm{A}$ rates and $\mathrm{C}_{\mathrm{i}}$ concentrations in both cultivars; WUE in 'Sweet Charlie' (Fig. 1, B.4) decreased by $79 \%$ after 1 week and by $64 \%$ in 'Chandler' after 2 weeks of high temperature (Fig. 1, A.4). 'Chandler' had 46\% higher WUE after 4 weeks of high temperature than 'Sweet Charlie'. These results suggest that 'Chandler' has higher A to E ratio under high temperature condition than 'Sweet Charlie'.

Responses of leaf temperatures and transpiration rates (E) to $40 / 35^{\circ} \mathrm{C}$ are shown in Figure 2. No treatment impact on leaf temperatures or $\mathrm{E}$ rates was observed for $20 / 15$ ${ }^{\circ} \mathrm{C}$, whereas $30 / 25{ }^{\circ} \mathrm{C}$ exerted a trend (data not shown) similar to that for $40 / 35^{\circ} \mathrm{C}$. Leaf temperatures increased in both cultivars after 1 week of exposure to high temperature; average leaf temperature was $39.3^{\circ} \mathrm{C}$. Trends of reduction in transpiration were similar to those of $g_{s}$ for both cultivars; $E$ rate was reduced after 2 and 3 weeks in 'Sweet Charlie' and 'Chandler', respectively. 'Chandler' plants showed constant $\mathrm{E}$ rates for 2 weeks but declined thereafter by an average of $16 \%$. Leaf temperature, however, remained constant throughout the duration of the experiment with an average of $38.5^{\circ} \mathrm{C}$. In contrast, 'Sweet Charlie' plants showed an average decline in $\mathrm{E}$

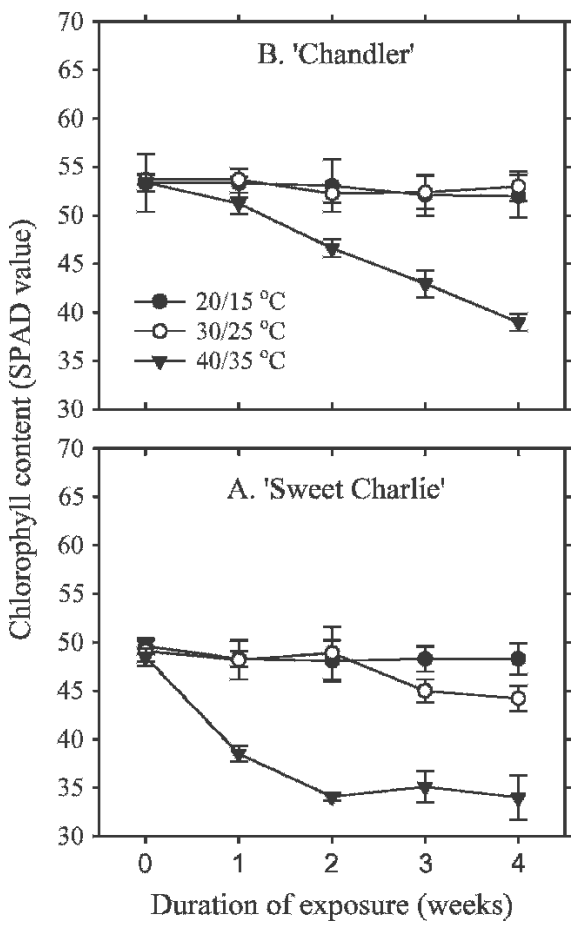

Fig. 5. Effect of three temperature regimes (20/15, $30 / 25$, or $40 / 35^{\circ} \mathrm{C}$ day/night [D/N] and 16/8-h photoperiod for 4 weeks) on relative chlorophyll content (SPAD value) of newly fully developed leaflet on 4-week-old 'Chandler' and 'Sweet Charlie' plants. Chlorophyll content was measured with the leaf chlorophyll meter at weekly intervals. Vertical bars through data points are standard errors; values smaller than symbols are not shown. Data represent means of nine plants grown in the same temperature regime.

rate of $28 \%$ after 2 weeks, which resulted in an average of $2.1{ }^{\circ} \mathrm{C}$ increase in leaf temperature. After 4 weeks of exposure, 'Chandler' leaves transpired $\approx 20 \%$ more and leaf temperature was $\approx 4{ }^{\circ} \mathrm{C}$ cooler than 'Sweet Charlie' leaves. Results showed that 'Sweet Charlie' had higher leaf temperature and lower $\mathrm{E}$ rate under high temperature than 'Chandler'. Transpiration rate of 'Sweet Charlie' was negatively related to leaf temperature $(r=-0.90)$ and positively related to $\mathrm{g}_{\mathrm{s}}(r=0.95)$; nonetheless, E rate of 'Chandler' was not significantly related to leaf temperature $(r=0.57)$ and was less related to $\mathrm{g}_{\mathrm{s}}$ rate $(r=0.86)$ than 'Sweet Charlie'. This suggests that different mechanisms for heat resistance might have been adopted by each cultivar. In contrast to 'Sweet Charlie', 'Chandler' leaves under heat stress managed to maintain constant $g_{s}$, resulting in cooler leaf temperature as a result of high transpiration. When transpiration rate of 'Sweet Charlie' (Fig. 3) was regressed against duration of exposure, there was a negative linear relationship between transpiration and time. The relationship explained most (97\%) of the variation in $\mathrm{E}$ rate with increasing time of exposure. 'Chandler', on the other hand, showed a negative linear relationship between transpiration and time although with low $r^{2}$ (0.40). 
Table 1. Response of total leaf area (LA); shoot, leaf, and root biomasses; and leaf, crown, and runner numbers of 4-week-old strawberry plants to $20 / 15,30 / 25$, or $40 / 35^{\circ} \mathrm{C}$ day/night $(\mathrm{D} / \mathrm{N})$ and 16/8-h photoperiod for 4 weeks of exposure. ${ }^{\mathrm{T}}$

\begin{tabular}{lrcc}
\hline & \multicolumn{3}{c}{ Temp $\left({ }^{\circ} \mathrm{C}\right)$} \\
\hline Parameter & $20 / 15$ & $30 / 25$ & $40 / 35$ \\
LA $\left(\mathrm{cm}^{2}\right)$ & $581 \mathrm{~b}^{\mathrm{y}}$ & $765 \mathrm{a}$ & $209 \mathrm{c}$ \\
Shoot biomass $(\mathrm{g})^{\mathrm{x}}$ & $8.4 \mathrm{a}$ & $8.8 \mathrm{a}$ & $6.1 \mathrm{~b}$ \\
Leaf biomass $(\mathrm{g})$ & $8.2 \mathrm{~b}$ & $10.0 \mathrm{a}$ & $6.6 \mathrm{c}$ \\
Root biomass $(\mathrm{g})$ & $11.3 \mathrm{a}$ & $9.4 \mathrm{~b}$ & $8.2 \mathrm{c}$ \\
Leaves (no.) & $32 \mathrm{ab}$ & $37 \mathrm{a}$ & $28 \mathrm{~b}$ \\
Crowns (no.) & $2.9 \mathrm{~b}$ & $3.4 \mathrm{a}$ & $1.1 \mathrm{c}$ \\
Runners (no.) & $2.2 \mathrm{~b}$ & $3.1 \mathrm{a}$ & ${ }^{\mathrm{w}}$ \\
\hline
\end{tabular}

${ }^{2}$ There was no significant difference between the cultivars; thus, data are averaged across cultivars for statistical analysis.

${ }^{y}$ Values are means of 18 plants grown in the same temperature regime. Means within parameter followed by different letter are significantly different at $P \leq 0.05$ using Fisher's protected LSD.

${ }^{\mathrm{x}}$ Shoot biomass includes crowns and petioles.

wNo runners.

Chlorophyll fluorescence. Temperature and duration of exposure significantly interacted with cultivar to influence chlorophyll fluorescence. Variable chlorophyll fluorescence $(\mathrm{Fv}=\mathrm{Fm}-\mathrm{Fo})$ and quantum yield efficiency of PSII $(\mathrm{Fv} / \mathrm{Fm})$ are shown in Figure 4. The Fv of both cultivars (Fig. 4, A.1 and B.1) followed the same trend as net $\mathrm{CO}_{2}$ assimilation rates (Fig. 1, A.1 and B.1); throughout the duration of exposure, low or medium temperature had no influence on $\mathrm{Fv}$, although $7 \%$ decline in $\mathrm{Fv}$ was observed in 'Sweet Charlie' (Fig. 4, B.1) after 4 weeks of exposure to $30 / 25{ }^{\circ} \mathrm{C}$. Regardless of the cultivar, plants grown in $40 / 35{ }^{\circ} \mathrm{C}$ showed early $\mathrm{Fv}$ decline. After 1 and 2 weeks of exposure, Fv declined in 'Sweet Charlie' (8\%) and 'Chandler' (6\%) (Fig. 4, A.1), respectively; nonetheless, there was no significant difference between the two cultivars after 4 weeks of exposure to high temperature.

Quantum yield efficiency of PSII is the function of Fv and Fm. At any time, Fv/Fm followed the trends of Fv (Fig. 4, A.1 and B.1) and A rates (Fig. 1, A.1 and B.1). Reduction of $\mathrm{Fv} / \mathrm{Fm}$ at $40 / 35{ }^{\circ} \mathrm{C}$ was the result of increase in Fo and decline in Fm rates (data not shown) in both cultivars, although there was significant difference between the cultivars. Efficiency of PSII in 'Chandler' (Fig. 4, A.2) was significantly higher at 3 weeks of exposure than that of 'Sweet Charlie' (Fig. 4, B.2). Collective results indicate that, under heat stress, 'Chandler' PSII is marginally more efficient than the PSII of 'Sweet Charlie'. The photosynthetic rate of 'Chandler' was positively related to $\mathrm{Fv}(r=0.97)$ and $\mathrm{Fv} / \mathrm{Fm}(r=$ $0.94)$ compared with $\mathrm{Fv}(r=0.92)$ and $\mathrm{Fv} / \mathrm{Fm}$ $(r=0.86)$ of 'Sweet Charlie'. The stronger relationship between $\mathrm{A}$ rates and $\mathrm{Fv} / \mathrm{Fm}$ in 'Chandler' might indicate that PSII is more thermostable that of 'Sweet Charlie'.

These findings confirm that temperatures above $30{ }^{\circ} \mathrm{C}$ reduce photosynthetic rate as a result of a reduction in PSII efficiency rather than a reduction in $g_{\mathrm{S}}$.

Table 2. Response of yield, fruit size, soluble solids concentration (SSC), and skin color ( ${ }^{\circ} \mathrm{h}$ ) of 'Chandler' and 'Sweet Charlie' 4-week-old plants to $20 / 15$ and $30 / 25^{\circ} \mathrm{C}$ day/night $(\mathrm{D} / \mathrm{N})$ and $16 / 8$-h photoperiod for 4 weeks of exposure.

\begin{tabular}{lccccc}
\hline Cultivar & Temp $(\mathrm{C})^{\mathrm{z}}$ & Yield $(\mathrm{g} / \mathrm{plant})$ & Fruit size $(\mathrm{g})$ & SSC $(\%)$ & Hue $^{\mathrm{y}}\left({ }^{\circ} \mathrm{h}\right)$ \\
\hline Chandler & $20 / 15$ & $9.2 \mathrm{a}^{\mathrm{x}}$ & $3.1 \mathrm{a}$ & $6.9^{\mathrm{NS}}$ & $15 \mathrm{~d}$ \\
Sweet Charlie & & $9.3 \mathrm{a}$ & $5.0 \mathrm{a}$ & $6.7^{\mathrm{NS}}$ & $44 \mathrm{bc}$ \\
& $30 / 25$ & $3.0 \mathrm{~b}$ & $1.0 \mathrm{~b}$ & $5.4^{\mathrm{NS}}$ & $56 \mathrm{a}$ \\
Chandler & & $6.0 \mathrm{ab}$ & $3.2 \mathrm{a}$ & $6.4^{\mathrm{NS}}$ & $37 \mathrm{c}$ \\
Sweet Charlie & & &
\end{tabular}

${ }^{\mathrm{z}} \mathrm{No}$ fruits in $40 / 35^{\circ} \mathrm{C}$.

${ }^{\mathrm{y}}$ Values (Atan $\mathrm{b} / \mathrm{a}$ ) calculated from a combination of Hunter $a$ and $b$ values.

${ }^{x}$ Means of nine plants grown in the same temperature regime. Means within column followed by different letter are significantly different at $P \leq 0.05$ using Fisher's protected LSD.

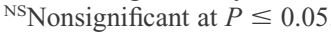

Chlorophyll content. Three-way interaction of cultivar by temperature by time was found for relative chlorophyll content. Regardless of temperature treatments, relative chlorophyll content (SPAD value) of 'Chandler' leaves was higher than that of 'Sweet Charlie' (Fig. 5). Throughout the test period, neither $20 / 15$ nor $30 / 25{ }^{\circ} \mathrm{C}$ treatments affected chlorophyll content of 'Chandler' leaves, but $30 / 25{ }^{\circ} \mathrm{C}$ reduced chlorophyll content of 'Sweet Charlie' by an average of $10 \%$ after 3 weeks of exposure. High temperature reduced chlorophyll content of both cultivars. Chlorophyll content of 'Sweet Charlie' leaves was reduced by $21 \%$ after 1 week exposure to $40 / 35{ }^{\circ} \mathrm{C} ; 13 \%$ reduction was observed for 'Chandler' after 2 weeks. Both 'Sweet Charlie' and 'Chandler' plants in $40 / 35{ }^{\circ} \mathrm{C}$ showed a constant decline over time, although 'Chandler' leaves had 13\% greater relative chlorophyll content at the end of the experiment. Chlorophyll content of different plant species under high temperature has shown mixed results. This study showed a decline under heat stress, which agrees with a decline reported in grapevines grown in a controlled environment (Fukuda and Matsumoto, 1988) and in mulberry (Morus spp. L.) plants exposed to high temperature for a short period of time (Chaitanya et al., 2001). Higher chlorophyll content was detected for heat-stressed grapevines in open air (Fukuda and Matsumoto, 1988). It was suggested that increase in chlorophyll content could be attributed to time of exposure and difference in plant species (Gulen and Eris, 2003), strength and source of stress (Dekov et al., 2000), or increase in leaf thickness, which led to concentration of more chlorophyll content (Abdelrahman, 1984). It has been suggested that longer exposure time of strawberry (Gulen and Eris, 2003) and tomato (Romero-Aranda et al., 2001) plants to high temperature increased chlorophyll content.

Plant growth, yield, and fruit quality. Cultivar had no impact on total leaf area (LA); shoot, leaf, and root biomasses; and leaf, crown, and runner numbers, so data were averaged across cultivars (Table 1). Reduction in A (Fig. 1, A.1 and B.1) was more pronounced in $40 / 35^{\circ} \mathrm{C}$ as indicated by declines in LA and in shoot and leaf biomasses. The optimal temperature for plant growth was
$30 / 25{ }^{\circ} \mathrm{C}$ as was $20 / 15{ }^{\circ} \mathrm{C}$. Plants at $30 / 25$ ${ }^{\circ} \mathrm{C}$ maintained greater LA, which generally paralleled leaf chlorophyll content (Fig. 5). Total leaf area of plants grown in $30 / 25{ }^{\circ} \mathrm{C}$ was $24 \%$ and $73 \%$ greater than that of plants in $20 / 15$ and $40 / 35{ }^{\circ} \mathrm{C}$, respectively. Runner development was inhibited by high temperature, whereas plants in $30 / 25^{\circ} \mathrm{C}$ had $29 \%$ more runners than in $20 / 15^{\circ} \mathrm{C}$. These findings are in agreement with Smeets's (1982) report that runner development was inhibited by 14 or $20^{\circ} \mathrm{C}$, whereas $26{ }^{\circ} \mathrm{C}$ was the optimal temperature. Leaf biomass was the highest in $30 / 25{ }^{\circ} \mathrm{C}$, but number of leaves was not significantly different from at $20 / 15^{\circ} \mathrm{C}$, which resulted in similar shoot biomass in both temperatures. Leaf number and leaf biomass in $40 / 35^{\circ} \mathrm{C}$ were reduced by $24 \%$ and $34 \%$, respectively, which resulted in $31 \%$ reduction in shoot biomass. Results indicate that dry matter accumulation was directly related to A rates, which agrees with earlier report (Ferrini et al., 1995) that positive correlation was found between the two variables. Plants in $30 / 25^{\circ} \mathrm{C}$, followed by those in $20 / 15^{\circ} \mathrm{C}$, produced more crowns than plants in $40 / 35^{\circ} \mathrm{C}$. Root growth was sensitive to temperatures above $20 / 15^{\circ} \mathrm{C}$; greatest growth was produced in $20 / 15^{\circ} \mathrm{C}(11.3 \mathrm{~g})$ followed by $9.4 \mathrm{~g}$ in $30 /$ $25{ }^{\circ} \mathrm{C}$. The least root biomass was observed in plants grown at $40 / 35^{\circ} \mathrm{C}$. These results indicate that strawberry roots are more sensitive to high temperature than shoot growth. Strawberry root growth in Hoagland solution was severely inhibited when plants were subjected to temperatures above $35{ }^{\circ} \mathrm{C}$ (Abdelrahman, 1984; Geater et al., 1997). Most of the growth inhibition of strawberry plants subjected to high root-zone temperature were associated with reduction in transpiration and leaf water potential (Geater et al., 1997).

A three-way interaction of cultivar by temperature by time was found for total marketable fruit yield and quality. Regardless of the cultivar, $40 / 35{ }^{\circ} \mathrm{C}$ treatment inhibited fruit development (Table 2). There were no nonmarketable fruits (disease or misshape) in either the $20 / 15^{\circ} \mathrm{C}$ or the $30 / 25^{\circ} \mathrm{C}$ treatment. Fruit yield for 'Chandler' was higher $(67 \%)$ at $20 / 15{ }^{\circ} \mathrm{C}$ than at $30 / 25{ }^{\circ} \mathrm{C}$, whereas no significant difference between the two temperatures was found for 'Sweet Charlie'. This suggests that 'Chandler' might have higher source-to-sink relationship at $20 / 15{ }^{\circ} \mathrm{C}$ than 
at $30 / 25^{\circ} \mathrm{C}$. More fruit transpiration or a low rate of dry matter accumulation in fruits (Miura et al., 1994) might also have occurred at $30 / 25{ }^{\circ} \mathrm{C}$, which reduced fruit yield of 'Chandler' as a result of reduction of fruit size. The difference between 'Chandler' and 'Sweet Charlie' suggests that high temperature effect on strawberry fruit yield and size is cultivar-dependent. Yield and fresh fruit weight are negatively related to increase in temperature (Mori, 1998). High temperature negatively affects fruit set in strawberries, depending on the cultivar, by reducing pollen viability and inhibiting pollen tube growth and elongation of pollen tube growth (Ledesma and Sugiyama, 2005). There was no significant reduction in 'Sweet Charlie' yield between $20 / 15$ and $30 / 25^{\circ} \mathrm{C}$, suggesting that 'Sweet Charlie' flowers might have produced heat-tolerant pollen (Ledesma and Sugiyama, 2005) that can survive $30 / 25{ }^{\circ} \mathrm{C}$. These findings suggest that the optimal temperature for 'Chandler' fruit yield and size was $20 / 15^{\circ} \mathrm{C}$, whereas 'Sweet Charlie' can produce comparable yield and fruit size in $30 / 25^{\circ} \mathrm{C}$ to those of plants in $20 / 15^{\circ} \mathrm{C}$. There was no significant difference in fruit size between the cultivars in $20 / 15^{\circ} \mathrm{C}$, but 'Sweet Charlie' produced larger fruits in $30 / 25{ }^{\circ} \mathrm{C}$ than 'Chandler'. No temperature impact was found on fruit SSC in either cultivar, which disagrees with Hardh and Hardh (1977) who reported that sugar content was reduced by high temperature. The discrepancy might be the result of differences in the environmental conditions and cultivars of the two experiments.

Fruit color of strawberries, skin redness, is one of the important fruit quality characteristics that determine differences between temperature treatments. This characteristic is measured by determining the hue value $\left({ }^{\circ} \mathrm{h}\right)$ from a combination of Hunter " $a$ " and " $b$ " values (data not shown). The lowest ${ }^{\circ} \mathrm{h}$ value or the greatest degree of redness was observed in 'Chandler' fruits in $20 / 15^{\circ} \mathrm{C}$; in contrast, 'Sweet Charlie' plants produced redder fruits in $30 / 25^{\circ} \mathrm{C}$. Within cultivar at the two temperatures, 'Chandler' fruits in $20 / 15^{\circ} \mathrm{C}$ were $73 \%$ redder than those in $30 / 25{ }^{\circ} \mathrm{C}$, whereas no significant difference was observed in 'Sweet Charlie' fruits. Between the cultivars, 'Chandler' fruits in $20 / 15^{\circ} \mathrm{C}$ were $66 \%$ redder than 'Sweet Charlie' fruits. Contrasting results occurred in $30 / 25{ }^{\circ} \mathrm{C}$; 'Sweet Charlie' fruits were $34 \%$ redder than 'Chandler' fruits. Strawberry skin redness was temperature dependent only for 'Chandler'. Although high temperature reduced color intensity of strawberry fruits (Hardh and Hardh, 1977), results of this study suggest that temperature effect on skin redness is cultivar-dependent.

Flower development. A significant interaction between cultivar, temperature, and time was found for open flower number and percentage of dead flower. Relationships between time of exposure to three temperature regimes and open flower number of 'Chandler' and 'Sweet Charlie' are shown in Figure 6. Quadratic relationships were observed at $30 / 25^{\circ} \mathrm{C}$, but positive and negative
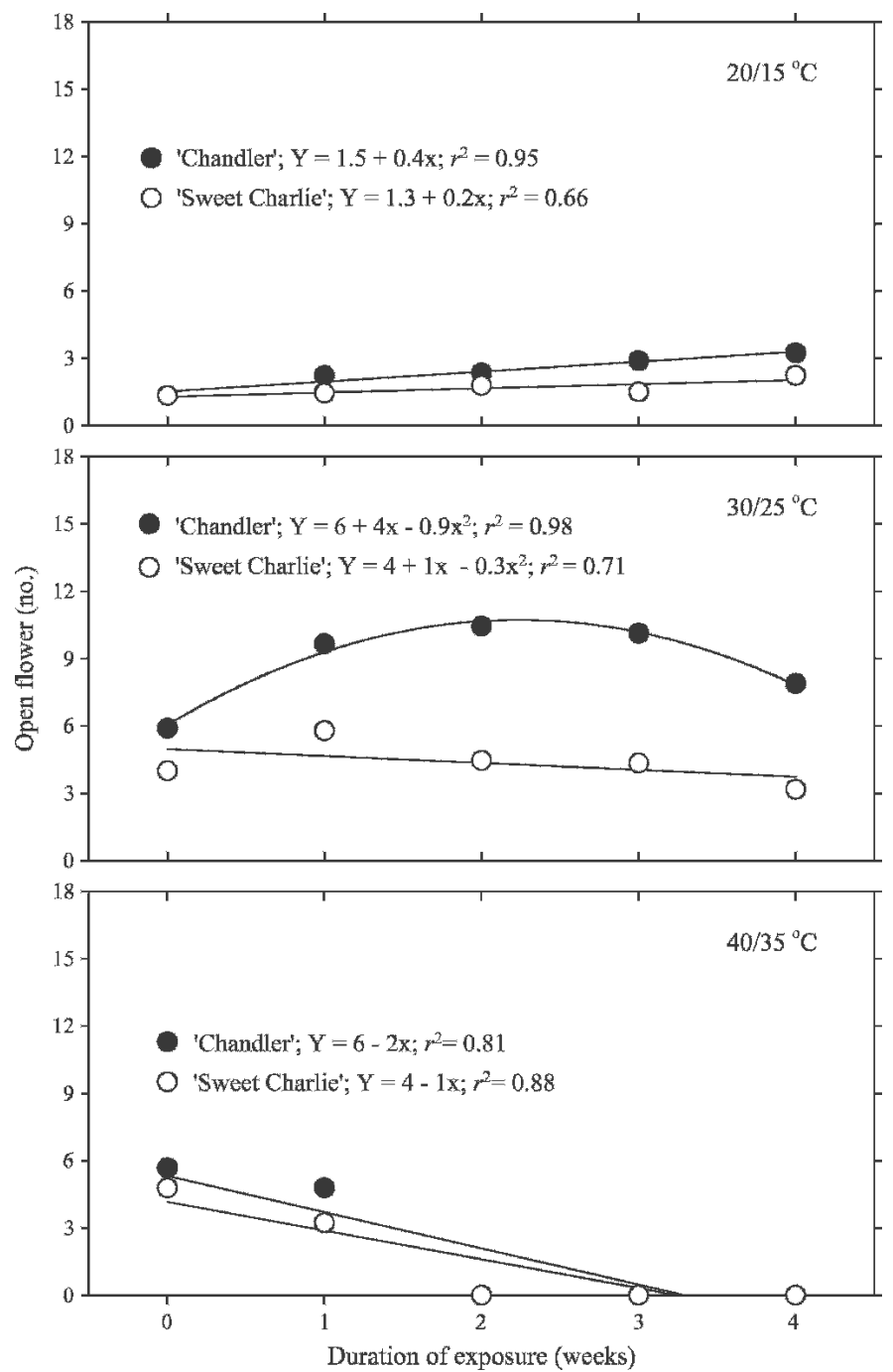

Fig. 6. Relationship between duration of exposure to three temperature regimes $\left(20 / 15,30 / 25\right.$, or $40 / 35^{\circ} \mathrm{C}$ day/night $[\mathrm{D} / \mathrm{N}])$ and 16/8-h photoperiod for 4 weeks) and open flower number of 4-week-old 'Chandler' $(\bullet)$ and 'Sweet Charlie' (X) plants. Data collected at weekly intervals. Lines represent linear regression analysis of the means. Data represent means of nine plants grown in the same temperature regime.

linear relationships were observed at 20/15 and $40 / 35{ }^{\circ} \mathrm{C}$, respectively. Flowers developed in the $20 / 15^{\circ} \mathrm{C}$ treatment as time of exposure increased, although a stronger relationship with time was observed in 'Chandler' $\left(r^{2}=0.95\right)$ than in 'Sweet Charlie' $\left(r^{2}=\right.$ 0.66 ), which resulted in higher yield in $20 / 15$ ${ }^{\circ} \mathrm{C}$ (Table 2). At $30 / 25{ }^{\circ} \mathrm{C}$, maximum open flower number for 'Chandler' was at 2 weeks, whereas maximum number for 'Sweet Charlie' was at 1 week exposure, but the number declined thereafter in both cultivars. For instance, increasing time of exposure to 4 weeks reduced open flower number by $24 \%$ and $45 \%$ in 'Chandler' and 'Sweet Charlie', respectively. Both cultivars exhibited a negative linear relationship between open flower number and time of exposure to $40 / 35^{\circ} \mathrm{C}$. For example, the number was reduced from 4.8 and 3.2 for 'Chandler' and 'Sweet Charlie', respectively, to no flowers as time of exposure to high temperature increased from 1 to 2 weeks. Results of this study show that, despite a positive linear relationship in 20/15
${ }^{\circ} \mathrm{C}$, more flowers were produced in $30 / 25^{\circ} \mathrm{C}$. Nevertheless, more than 2 weeks at $30 / 25^{\circ} \mathrm{C}$ can be detrimental to flower development for both cultivars. Strawberry flower initiation was delayed at $20^{\circ} \mathrm{C}$ and 16 -h photoperiod, whereas $26{ }^{\circ} \mathrm{C}$ initiated early and more flowers (Smeets, 1982). Continuous flowering at $30 / 25{ }^{\circ} \mathrm{C}$ in 'Chandler' for 2 weeks compared with 1 week in 'Sweet Charlie' suggests that flower initiation is dependent on the ability of a cultivar to form flower buds in response to temperature under long-day conditions (Heide, 1977). Biosynthesis of a flowering inhibitor (Vince-Prue et al., 1976) might have increased to a level that led to inhibition of flower initiation or flower bud formation in 'Chandler' and 'Sweet Charlie' after 2 weeks and 1 week of $30 / 25^{\circ} \mathrm{C}$, respectively.

Time of exposure to $30 / 25$ and $40 / 35^{\circ} \mathrm{C}$ increased percentage of dead flower in both cultivars (Fig. 7). 'Chandler' was not influenced by 2 weeks of exposure to $30 / 25^{\circ} \mathrm{C}$ (Fig. 7), but the value increased by $64 \%$ as time of exposure increased from 2 to 3 weeks. 

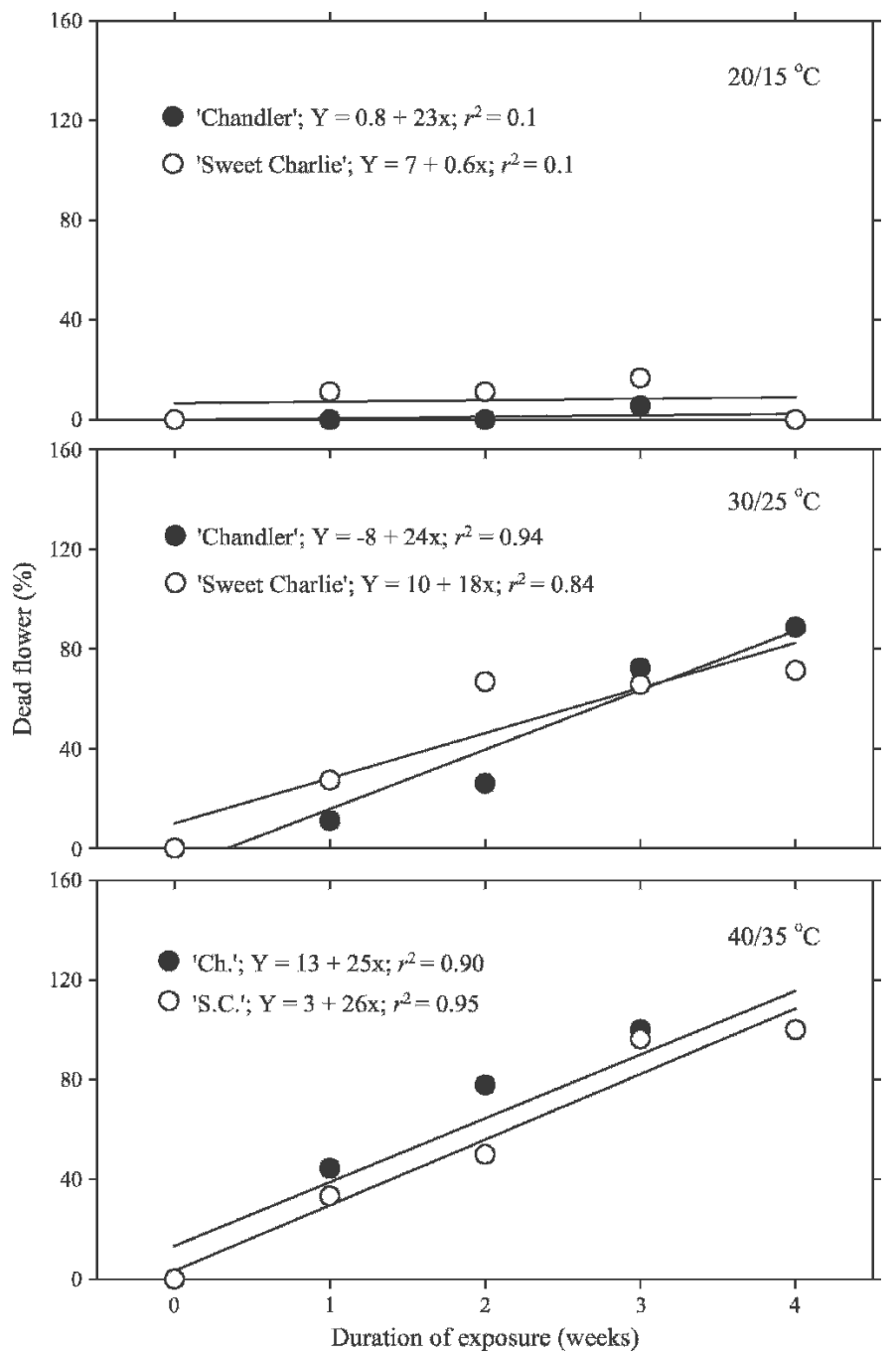

Fig. 7. Relationship between duration of exposure to three temperature regimes $\left(20 / 15,30 / 25\right.$, or $40 / 35^{\circ} \mathrm{C}$ day/night $[\mathrm{D} / \mathrm{N}]$ and 16/8-h photoperiod for 4 weeks) and percentage of dead flower of 4-week-old 'Chandler' (•) and 'Sweet Charlie' (X) plants. Data collected at weekly intervals. Lines represent linear regression analysis of the means. Data represent means of nine plants grown in the same temperature regime.

Earlier increase in the percentage of dead flower of 'Sweet Charlie' was observed as time of exposure increased. For example, there was an increase from $27 \%$ to $67 \%$ as time of exposure increased from 1 to 2 weeks. In contrast, the rate at $40 / 35{ }^{\circ} \mathrm{C}$ increased from $44 \%$ and $33 \%$ to $78 \%$ and $50 \%$ in 'Chandler' and 'Sweet Charlie', respectively, as time of exposure increased from 1 to 2 weeks. Regardless of cultivar and time of exposure, high temperature was the most detrimental to flower initiation, whereas 20/ $15{ }^{\circ} \mathrm{C}$ was the least. Interaction between cultivar and time of exposure impacted flower survival at $30 / 25^{\circ} \mathrm{C}$. For example, in week 2, percentage of dead flower for 'Chandler' was $26 \%$ compared with $67 \%$ for Sweet Charlie, which suggests that $30 / 25^{\circ} \mathrm{C}$ affects flower initiation and survival but that the effect is cultivar-dependent.

In conclusion, high temperature severely reduced strawberry growth and yield. Photosynthesis inhibition was a primary factor of injury from high temperature, and strawberry cultivars differed in their response to heat stress. Plant growth at moderately high temperature $\left(30 / 25^{\circ} \mathrm{C}\right)$ hardly contributed to the reduction in photosynthesis; reduction was associated with relatively no change in $\mathrm{Fv}$ / Fm, suggesting that there was no damage to PSII in $30 / 25{ }^{\circ} \mathrm{C}$. The $40 / 35{ }^{\circ} \mathrm{C}$ treatment caused more reduction in thermostability of the photosynthesis apparatus of the relatively heat-sensitive 'Sweet Charlie' than it caused in 'Chandler'. Results of this study show that the main factor for photosynthesis reduction was more related to changes in the efficiency of PSII than to stomatal activities. There was no cultivar impact on shoot or root growth and $30 / 25^{\circ} \mathrm{C}$ was the optimal temperature for shoot growth but $20 / 15^{\circ} \mathrm{C}$ was the optimal temperature for root growth. 'Chandler' plants had higher WUE, suggesting that, under heat stress, 'Chandler' might have higher ratio of photosynthetic rate to transpiration than 'Sweet Charlie'. High temperature inhibited flower and fruit set in both cultivars. The $20 / 15^{\circ} \mathrm{C}$ was the optimal temperature for fruit yield and fruit size in 'Chandler', whereas 'Sweet Charlie' produced yield and fruit size in $30 / 25{ }^{\circ} \mathrm{C}$ comparable to that of plants in $20 / 15^{\circ} \mathrm{C}$. Strawberry skin redness was temperature dependent only for 'Chandler'. Despite a positive linear relationship between flower development and duration of exposure to $20 / 15^{\circ} \mathrm{C}$ in both cultivars, a quadratic relationship occurred for $30 / 25^{\circ} \mathrm{C}$. More than 2 weeks of $30 / 25{ }^{\circ} \mathrm{C}$ can be detrimental to flower development, suggesting that $30 / 25^{\circ} \mathrm{C}$ affects flower initiation and survival but that the effect of duration of exposure is cultivar-dependent.

Although 'Chandler' is more resistant to high temperature, future investigations involving comparison of the two cultivars will be needed for a better understanding of high temperature effect during the development of reproductive stages. Effect of chemicals and evaporative cooling system to alleviate heat stress should also be considered in investigations of heat tolerance during the reproductive stages.

\section{Literature Cited}

Abdelrahman, M.H. 1984. Growth and productivity of strawberry cultivars at high temperatures. PhD Thesis, Kans. State Univ., Manhattan.

Adams, S.R., K.E. Cockshull, and C.R.J. Cave. 2001. Effect of temperature on the growth and development of tomato fruits. Annu. Bot. 88:869-877.

Berry, J. and O. Björkman. 1980. Photosynthetic response and adaptation to temperature in higher plants. Ann. Rev. Plant Physiol. 31:491-543.

Candolfi-Vasconcelos, M.C. and W. Koblet. 1991. Influence of partial defoliation on gas exchange parameters and chlorophyll content of fieldgrown grapevines-Mechanisms and limitations of the compensation capacity. Vitis $30: 129-141$

Chaitanya, K.V., D. Sundaret, and A. Ramachndra Reddy. 2001. Mulberry leaf metabolism under high temperature stress. Biol. Plant. 3:379-384.

Chaumont, M., M.L. Osorio, M.M. Chaves, H. Vanacker, J.F. Morot-Gaudry, J. Francois, and C.H. Foyer. 1997. The absence of photoinhibition during the mid-morning depression and photosynthesis in Vitis vinifera grown in semiarid and temperate climates. J. Plant Physiol. 150:743-751.

Dekov, I., T. Tsonev, and I. Yordanov. 2000. Effects of water stress and high-temperature stress on the structure and activity of photosynthetic apparatus of Zea mays and Helianthus annuus. Photosynthetica 38:361-366.

Ferrini, F., G.B. Mattii, and F.P. Nicese. 1995. Effect of temperature on key physiological responses of grapevine leaf. Amer. J. Enol. Viticult. 46:375-379.

Fukuda, S. and O. Matsumoto. 1988. A propagation method by nutrient film technique culture of forcing strawberry: A propagation method of NFT strawberry under high temperature in summer. Bul. Yamaguchi Agr. Expt. Sta. 40:27-33.

Geater, C.A., G.R. Nonnecke, W.R. Graves, A.S. Aiello, and C.A. Dilley. 1997. High rootzone temperatures inhibit growth and development of Fragaria species. Fruit Var. J. 51: 94-101. 
Gulen, H. and A. Eris. 2003. Some physiological changes in strawberry (Fragaria x ananassa 'Camarosa') plants under heat stress. J. Hort. Sci. Biotechnol. 78:894-898.

Gulen, H. and A. Eris. 2004. Effect of heat stress on peroxidase activity and total protein content in strawberry plants. Plant Sci. 166: 739-744.

Hardh, K. and J.E. Hardh. 1977. Studies on quality of vegetables and strawberries at different latitudes in Finland. Annales Agriculturae Fenniae 16:19-26.

Heide, O.M. 1977. Photoperiod and temperature interactions in growth and flowering of strawberry. Physiol. Plant. 40:21-26.

Hellman, E. and J. Travis. 1988. Growth inhibition of strawberry at high temperatures. Adv. Strawberry Production 7:36-38.

Henning, J.C. and R.H. Brown. 1986. Effects of irradiance and temperature on photosynthesis in C3, C4, and C3/C4 Panicum species. Photosyn. Res. 10:101-112.

Hunter, R.S. and R.W. Harold. 1987. The measurement of color. 2nd ed. Wiley, New York.

Kadir, S., N. Tisserat, and R. Bauernfeind. 2006. Midwest commercial small fruit and grape spray guide. Kans. State Univ. S-146.

Ledesma, N.A., S. Kawabata, and N. Sugiyama. 2004. Effect of high temperature on protein expression in strawberry plants. Bio. Planta 48:73-79.

Ledesma, N.A. and N. Sugiyama. 2005. Pollen quality and performance in strawberry plants exposed to high-temperature stress. J. Amer. Soc. Horti Sci. 130:341-347.

Medrano, H., J.M. Escalona, J. Cifre, J. Bota, and J. Flexas. 2003. A ten-year study on the physiology of two Spanish grapevine cultivars under field conditions: effect of water availability from leaf photosynthesis to grape yield and quality. Funct. Plant Biol. 30:607-619.

Miura, H., M. Yoshida, and A. Yamasaki. 1994. Effect of temperature on the size of strawberry fruit. J. Jpn. Soc. Hort. Sci. 62: 769-774.

Mori, T. 1998. Effect of temperature during flower bud formation on achene number and fresh weight of strawberries. J. Jpn. Soc. Hort. Sci. 67:396-399.

Mulholland, B.J., R.N. Edmondson, M. Fussell, J. Basham, and L.C. Ho. 2003. Effects of high temperature on tomato summer fruit quality. J. Hort. Sci. Biotechnol. 78:365-374.

Nishiyama, M., W. Ohkawa, and K. Kanahama. 2003. Effect of photoperiod on the development of inflorescence in everbearing strawberry 'Summerberry' plants grown at high temperature. Tohoku J. Agr. Res. 53:43-52.

Olson, B.L.S., K. Al-Khatib, P. Stahlman, and P.J. Isakson. 2000. Efficacy and metabolism of MON 37500 in Tititicum aestivum and weedy grass species as affected by temperature and soil moisture. Weed Sci. 48:541-548.

Paulsen, G.M. 1994. High temperature responses of crop plants, p. 365-389. In: K.J. Boot, J.M. Bennett, T.R. Sinclair, and G.M. Paulsen (eds.).
Physiology and determination of crop yield. ASA, CSSA, SSSA, Madison, Wisc.

Polito, V.S., K.D. Larson, and K. Pinney. 2002. Anatomical and histochemical factors associated with bronzing development in strawberry fruit. J. Amer. Soc. Hort. Sci. 127:355-357.

Renquist, A.R., P.J. Breen, and L.W. Martin. 1983. Influences of water stress and temperature on leaf elongation in strawberry. Scientia Hort. 18:77-85.

Romero-Aranda, R., T. Soria, and J. Cuartero. 2001. Tomato plant-water uptake and plantwater relations under saline growth conditions. Plant Sci. 160:265-272.

Smeets, L. 1982. Effects of chilling on runner formation and flower initiation in the everbearing strawberry. Scientia Hort. 17:4348.

Vara-Prasad, P.V., P.Q. Craufurd, and R.J. Summerfield. 1999. Sensitivity of peanut to timing of heat stress during reproductive development. Crop Sci. 39:1352-1357.

Vince-Prue, D., G. Guttridge, and M.W. Buck. 1976. Photocontrol of petiole elongation in light-grown strawberry plants. Planta 131: 109-114.

Zang, W., M. Seki, and S. Furusaki. 1997. Effect of temperature and its shift on growth and anthocyanin production in suspension cultures of strawberry cells. Plant Sci. 127:207-214. 